\title{
Nurse's interventions in preventing falls in hospitalized children: scoping review
}

\author{
Intervenções do enfermeiro na prevenção de quedas na criança hospitalizada: scoping review \\ Intervenciones del enfermero en la prevención de caídas en el niño hospitalizado: scoping review
}

\section{Alexandra Margarida Ribeiro Brás ORCID: 0000-0002-1002-8248}

Margarida Maria de Sousa Lourenço Quitério" ORCID: 0000-0002-3610-5192

Elisabete Maria Garcia Teles Nunes" ORCID: 0000-0001-7598-0670

'Hospital Vila Franca de Xira. Lisboa, Portugal. "Universidade Católica Portuguesa. Lisboa, Portugal.

How to cite this article:

Brás AMR, Quitério MMSL, Nunes EMGT. Nurse's interventions in preventing falls in hospitalized children: scoping review. Rev Bras Enferm. 2020;73(Suppl 6):e20190409. doi: http://dx.doi.org/10.1590/0034-7167-2019-0409

Corresponding author:

Alexandra Margarida Ribeiro Brás E-mail: alexandra.bras@hotmail.com

EDITOR IN CHIEF: Dulce Barbosa ASSOCIATE EDITOR: Priscilla Valladares Broca

Submission: 08-13-2019

Approval: 07-18-2020

\begin{abstract}
Objectives: map both nursing interventions for the prevention of falls in paediatric age during hospitalization and the instruments for assessing the risk of falls in paediatrics. Methods: scoping review according to the protocol of Joanna Briggs Institute, with acronym PCC ( $P$ - children, $C$ - fall preventive nursing interventions and instruments for assessing the risk of falling, $\mathrm{C}$ - hospital admission), in three sources of information (EBSCO, PubMed and SciELO). Results: the sample consisted of seven articles. The education of the child/ family is the basis of the interventions, and the instruments for assessing the risk of falling identified were: Humpty Dumpty Falls Scale, GRAF PIF, CUMMINGS, I'M SAFE and CHAMPS. Conclusions: the education of children/parents on preventive measures is important and should be reinforced during hospitalization, using different methodologies. The Humpty Dumpty Falls Scale was the most analyzed.

Descriptors: Fall; Prevention; Nursing; Paediatrics; Risk.
\end{abstract}

\section{RESUMO}

Objetivos: mapear tanto as intervenções de enfermagem de prevenção de quedas em idade pediátrica durante o internamento hospitalar quanto os instrumentos de avaliação do risco de queda em pediatria. Métodos: scoping review segundo protocolo de Joanna Briggs Institute, com acrónimo PCC ( $\mathrm{P}$ - crianças, $\mathrm{C}$ - intervenções de enfermagem preventivas de queda e instrumentos de avaliação do risco de queda, $\mathrm{C}$ - internamento hospitalar), em três fontes de informação (EBSCO, PubMed e SciELO). Resultados: a amostra foi constituída por sete artigos. A educação da criança/família é a base das intervenções, e os instrumentos de avaliação do risco de queda identificados foram: Humpty Dumpty Falls Scale, GRAF PIF, CUMMINGS, I'M SAFE e CHAMPS. Conclusões: a educação das crianças/pais sobre as medidas preventivas é importante e deve ser reforçada durante o internamento, sendo utilizadas diferentes metodologias. A escala Humpty Dumpty Falls Scale foi a mais analisada.

Descritores: Queda; Prevenção; Enfermagem; Pediatria; Risco.

\section{RESUMEN}

Objetivos: mapear tanto las intervenciones de enfermería de prevención de caídas en edad pediátrica durante el internamiento hospitalario cuanto los instrumentos de evaluación del riesgo de caída en pediatría. Métodos: scoping review según protocolo de Joanna Briggs Institute, con acrónimo PCC (P - niños, C - intervenciones de enfermería preventivas de caída e instrumentos de evaluación del riesgo de caída, C - internamiento hospitalario), en tres fuentes de información (EBSCO, PubMed y SciELO). Resultados: la muestra ha sido constituida por siete artículos. La educación del niño/familia es la base de las intervenciones, y los instrumentos de evaluación del riesgo de caída identificados han sido: Humpty Dumpty Falls Scale, GRAF PIF, CUMMINGS, I'M SAFE y CHAMPS. Conclusiones: la educación de los niños/padres sobre las medidas preventivas es importante y debe ser reforzada durante el internamiento, siendo utilizadas diferentes metodologías. La escala Humpty Dumpty Falls Scale ha sido la más analizada.

Descriptores: Caída; Prevención; Enfermería; Pediatría; Riesgo. 


\section{INTRODUCTION}

Hospital units have a duty to prevent and eliminate damage and non-maleficence, being responsible for the safety of their facilities and, thus, for creating an environment appropriate to the age and development of their customers.

In 2005, the World Health Organization (WHO) entered into a partnership with the Joint Commission International $(\mathrm{JCl})$, the main health accreditation agency, which works to continuously improve the safety and quality of care provided to users, having issued, in 2006, international safety targets. These should be implemented in hospitals in order to improve their care processes in the area of safety and quality, considering excellence in care ${ }^{(1)}$.

Promoting safety is also a priority for nurses; they must develop interventions that lead to risk reduction and the creation of a safe environment. In the regulation of common competencies of the specialist nurse, it is stated that he should "promote a physical, psychosocial, cultural and spiritual environment that generates security and protection of individuals/groups", demonstrating for this knowledge about the creation of a safe environment for users, as well as "managing risk at the institutional or functional unit level", collaborating in the definition of resources for the provision of safe care and involving employees in risk management ${ }^{(2)}$.

The European Strategy for of Child and Adolescent Health and Development (WHO) addresses accidents as a priority and, for 2020, predicts that they will be the third leading cause of death in the world ${ }^{(3)}$. In Portugal, the National Child and Youth Health Program stresses that the safety of the environment and accidents are a constant feature in the early care provided to children ${ }^{(4)}$.

In this sense, preventing accidents and teaching the child to protect themselves from risky situations are issues that are part of their education and development process. The specialist nurse in child and paediatric health is the health professional who, in partnership with the child and with the family/significant person, has a fundamental role in promoting health through informative, educational and preventive actions with the child and family/ significant person in any context in which they are. On the other hand, there is also the competence to promote growth, child development and transmit anticipatory guidance to children/ families in order to maximize the potential of their development ${ }^{(5)}$.

There are several models of nursing that aim to improve the quality of care and promote safety; one of them is the Pender Health Promotion Model, developed in 1982. This model is not limited to explaining disease prevention behaviors, but identifying what behaviors people can adopt to improve health. Thus, it highlights the person's active role in the management of their health behavior, reflecting the perspective of the behavioral sciences. In this way, people try to create living conditions that allow them to express their health potential, with reflective awareness and appreciation of their own competencies. They value growth that they see as positive and seek a balance between change and stability, seeking to self-regulate their behavior. It is also clear that people interact with the environment, transforming it and being transformed by it. This interpersonal environment includes health professionals who influence people throughout their life cycle. However, for behavioral change to occur, it is necessary to reconfigure the person-environment interaction patterns ${ }^{(6)}$. In terms of child health care, "person" becomes the child and the family working in partnership in a process of shared negotiation respecting the family and their skills, desires and anxieties. The child/family is the entity that has the potential to change health behaviors, committing to behavior that anticipates personally valued benefits. Families and health care providers are important sources of interpersonal influence that can increase or decrease commitment and the adoption of health-promoting behaviors.

Regarding falls in paediatrics, WHO states that they are the second leading cause of death or accidental injury worldwide ${ }^{(3)}$. About 9 children suffer a fall daily with serious consequences, being the main cause of going to the emergency room and hospitalization. Mostly, falls occur between 0-4 years and 5-9 years ${ }^{(7)}$.

The study by the Association for Child Safety Promotion (APSI), in 2011, on accidental falls in Portugal (2000-2009), reveals that about 40,000 children had to be hospitalized ${ }^{(8)}$. More recently, in 2017 (data from 2012-2016), it was possible to verify that falls were responsible for $61 \%$ of hospitalizations that occurred ${ }^{(9)}$.

According to the $\mathrm{WHO}$, falls are defined as an event whose result is to be inadvertently on the ground or at a lower level, with no relevance to the occurrence of injury or not ${ }^{(10)}$. The same is reinforced by the International Classification for Nursing Practice (ICNP), which defines falling due to the focus of falling: "executing a descent of a body from a higher level to a lower level due to imbalance, fainting or inability to support weights and remain in the vertical"(11).

Children are a risk group, and their falls are related to their stage of development, acquisition of motor skills, especially gait, their inability to assess risk and innate curiosity that leads to more challenging behaviors.

The fall can be classified into three categories: expected physiological falls (due to factors such as age, pathology, medication or medical procedures); unforeseen physiological falls (are related to physiological factors and are not classified as risk in the assessment scales); accidental falls (due to environmental/ organizational conditions, that is, extrinsic factors) ${ }^{(12)}$.

The paediatric fall rate during hospitalization is 1.23 per 1,000 children/day ${ }^{(13)}$, and the expected physiological falls represent a total of $78 \%$; and accidental falls, $14 \%{ }^{(12)}$. Thus, it is not only the expected physiological falls that deserve special attention, but also the falls resulting from environmental factors - such as beds unsuitable for children, non-use or the incorrect use of protection bars, disorganization in the toy room, among others - should be the target of our care ${ }^{(13)}$.

With regard to $\mathrm{JCI}$ International Goals, the reduction of the risk of injuries resulting from falls in patients is included in Goal 6, which leads the institution to: assess the risk of falling; implement measures to reduce the risk of falls; and implement response measures in the event of the fall of your patients ${ }^{(1)}$.

The National Patient Safety Policy 2015-2020 aims, in its objectives, to prevent the occurrence of falls. The consequences of failure to identify users at risk of falling, failure to assess risk and failure to implement appropriate and personalized prevention interventions lead to risk situations ${ }^{(14)}$.

The North American Nursing Diagnosis Association - International (NANDA-I) stresses that nurses cannot reverse the fall, but can prevent its occurrence. The corresponding nursing diagnosis is: Risk of falling - risk of increased susceptibility to falls that can cause physical damage ${ }^{(15)}$. 
The document "The Conceptual Framework for the International Classification for Patient Safety" defines "risk" as the probability of an incident occurring; and "preventable"(16) as something that is accepted by the community as excusable in a given set of circumstances. Thus, we entered the area of risk management ${ }^{(17)}$.

The factors that influence the risk of falling in children may be intrinsic — sex (male), altered level of consciousness, history of previous fall, age below 3 years, ability to mobilize; or extrinsic - parental involvement in safety culture and environmental conditions such as cribs, crates and a playroom ${ }^{(15)}$.

Prevention strategies must be comprehensive, multifaceted, emphasizing education, training, creating safe environments, giving priority to both fall-related research and the definition of effective risk reduction policies ${ }^{(10)}$. A correct intervention, based on good practices, requires resorting to instruments for assessing the risk of falls to all children, with the following objectives: identifying the level of risk, acting according to the level of risk, preventing possible falls, thus increasing safety ${ }^{(18)}$. Thus, it appears that one of the main interventions to reduce the rate of falls in children is the assessment of such risk by means of valid and appropriate instruments for them.

Thus, research questions were defined: What are the nursing interventions for the prevention of falls in children during hospitalization? What are the instruments for assessing the risk of falls in paediatrics?

\section{OBJECTIVES}

To map both the interventions by the nurse that prevent falls in children, in the context of hospitalization, and the risk assessment instruments adapted to this population.

\section{METHODS}

They were defined according to the scoping review methodology, according to the protocol of Joanna Briggs Institute ${ }^{(19)}$, the following research objectives mentioned; and the acronym PCC was used: Population (P), Concept (C) and Context (C). Therefore, the following inclusion criteria were considered: $\mathrm{P}$ - children $(0$ to 18 years old); $C$ - fall preventive nursing interventions and fall risk assessment instruments; $\mathrm{C}$ - in the context of hospitalization.

Articles in Portuguese and English were included, available in a five-year time window (January 2013 to April 2018) and in full. The exclusion criteria were: non-scientific articles (opinion articles, field notes, conference notes, studies or academic works) or scientific articles that do not meet the inclusion criteria described.

\section{Research strategies}

In a first phase, a search was made in the electronic databases EBSCO, SciELO and PubMed, and in the Mesh platform, with the objective of conducting a floating research on the theme and identifying the most common descriptors used in the literature.

In a second phase, research was carried out in three electronic databases - EBSCO (CINAHL and MEDLINE), SciELO and PubMed using the descriptors Mesh (fall; prevention; paediatric nursing) and boolean operator (AND).
The research equation used was as follows:

- EBSCO (CINAHL and MEDLINE): fall AND prevention AND paediatric nursing;

- SciELO: (fall) AND (prevention) AND (paediatric nursing);

- PubMed: (fall[All Fields] AND ("preventionand control"[Subheading] OR ("prevention"[All Fields] AND"control"[All Fields]) OR"prevention and control"[All Fields] OR "prevention"[All Fields]) AND ("paediatric nursing"[All Fields] OR "paediatric nursing"[MeSH Terms] OR ("paediatric"[All Fields] AND "nursing"[All Fields]) OR "paediatric nursing"[All Fields])) AND ("2013/01/01"[PDAT] :"2018/04/24"[PDAT]).

In a third phase, a search of the grey literature was carried out using the Google search engine, whose contents were not included in the results, taking into account the inclusion and exclusion criteria established.

\section{RESULTS}

From the studies found and that met the eligibility criteria, a total of 21 articles emerged, progressively excluded: by repetition (5 articles: $2 \mathrm{EBSCO}+3$ PubMed), title analysis/abstract (4 articles); inaccessibility ( 1 article) and by comprehensive analysis of the article ( 4 articles).

Two reviewers, independently, examined the full text of the articles to see if they met the inclusion criteria.

In Figure 1, the selection process of the articles with a PRISMA flow chart is presented, with the seven included in the final sample (two articles from EBSCO [CINAHL and MEDLINE] ${ }^{(20-21)}$, four articles from PubMed ${ }^{(22-25)}$ and one article from SciELO ${ }^{(26)}$ ).

The final sample consists of an article with qualitative methodology, four with quantitative methodology, and two integrative reviews (Chart 1).

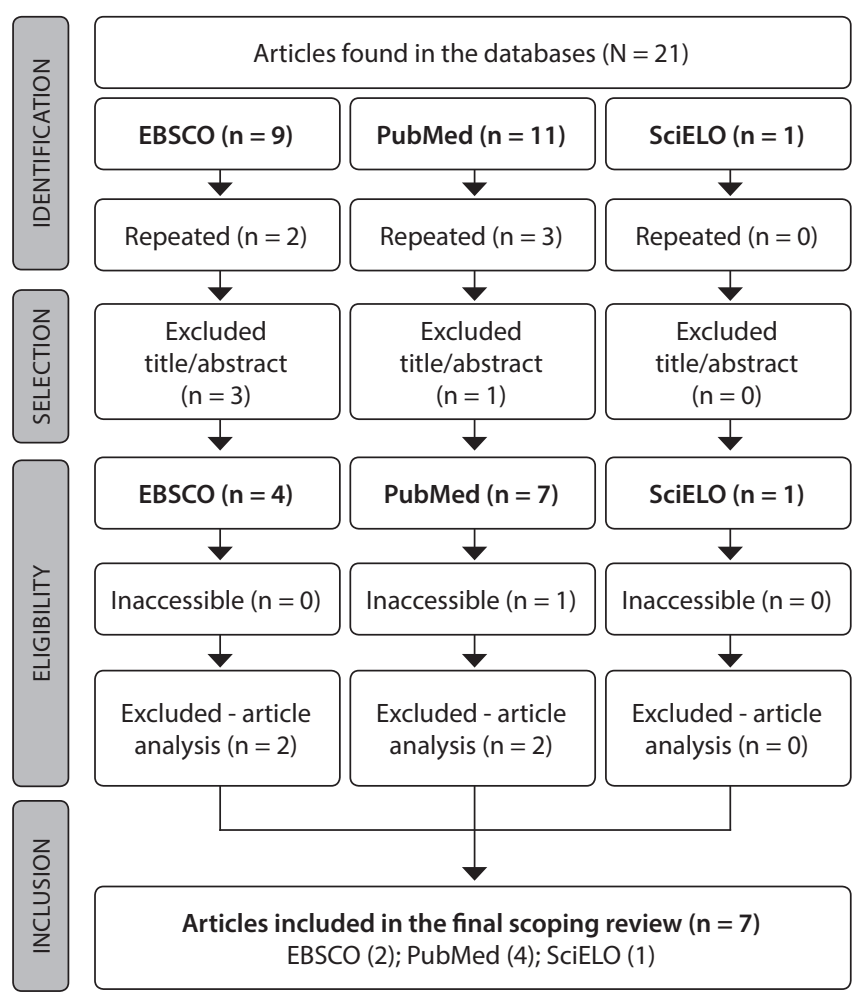

Figure 1 - PRISMA flowchart of the article selection process, according to Joanna Briggs Institute ${ }^{(19)}$ 
To improve the understanding of the results of each study, they will be presented in a chart and according to the proposed research questions (Chart 2 refers to the first question; and Chart 3, to the second).

Chart 1 - Articles included in the analysis of the results

\begin{tabular}{|c|c|c|c|c|}
\hline Title & Author & Year & Country & $\begin{array}{l}\text { Review / } \\
\text { Study }\end{array}$ \\
\hline $\begin{array}{l}\text { An Integrative } \\
\text { Review } \\
\text { of Paediatric Fall Risk } \\
\text { Assessment Tools }^{(22)}\end{array}$ & $\begin{array}{c}\text { DiGerolamo K, } \\
\text { Davis KF }\end{array}$ & 2017 & USA & $\begin{array}{l}\text { Integrative } \\
\text { review }\end{array}$ \\
\hline $\begin{array}{l}\text { Competencies of } \\
\text { the Nurse in the } \\
\text { Prevention of Falls } \\
\text { in Children in the } \\
\text { Light of the Galway } \\
\text { Consensus } \\
\text { (26) }\end{array}$ & $\begin{array}{l}\text { Gurgel, S., } \\
\text { Ferreira, A., } \\
\text { Sandoval, L., } \\
\text { Araújo, P., } \\
\text { Galvão, M. e } \\
\text { Lima, F. }\end{array}$ & 2017 & Brazil & $\begin{array}{l}\text { Quantitative } \\
\text { - Cross- } \\
\text { sectional } \\
\text { description }\end{array}$ \\
\hline $\begin{array}{l}\text { Development of } \\
\text { a Paediatric Fall Risk } \\
\text { And Injury } \\
\text { Reduction } \\
\text { Program }^{(20)}\end{array}$ & $\begin{array}{l}\text { Kramlich DL, } \\
\text { Dende D. }\end{array}$ & 2016 & USA & Qualitative \\
\hline $\begin{array}{l}\text { Impatient Falls } \\
\text { in Freestanding } \\
\text { Children's } \\
\text { Hospitals }^{(21)}\end{array}$ & $\begin{array}{c}\text { Jamerson, } \mathrm{P}, \\
\text { et all }\end{array}$ & 2014 & USA & $\begin{array}{l}\text { Quantitative } \\
\text { - Cross- } \\
\text { sectional } \\
\text { description }\end{array}$ \\
\hline $\begin{array}{l}\text { Paediatric } \\
\text { Falls: Effect } \\
\text { of prevention } \\
\text { measures and } \\
\text { characteristics of } \\
\text { paediatric wards }{ }^{(23)}\end{array}$ & $\begin{array}{l}\text { Fujita, Y., } \\
\text { Fujita, M., } \\
\text { Fujiwara, C. }\end{array}$ & 2013 & Japan & $\begin{array}{l}\text { Quantitative } \\
\text { - Cross- } \\
\text { sectional } \\
\text { description }\end{array}$ \\
\hline $\begin{array}{l}\text { A case-control study } \\
\text { of paediatric falls } \\
\text { using electronic } \\
\text { medical records }^{(24)}\end{array}$ & $\begin{array}{l}\text { Messmer PR, } \\
\text { Williams PD, } \\
\text { Williams AR. }\end{array}$ & 2013 & USA & $\begin{array}{l}\text { Quantitative } \\
\text { - Control } \\
\text { case }\end{array}$ \\
\hline $\begin{array}{l}\text { An interdisciplinary } \\
\text { momentary } \\
\text { confluence of } \\
\text { events model to } \\
\text { explain, minimize, } \\
\text { and prevent } \\
\text { paediatric patient } \\
\text { falls and fall-related } \\
\text { injuries }^{(25)}\end{array}$ & $\begin{array}{c}\text { Ryan-Wenger } \\
\text { NA, } \\
\text { Dufek JS. }\end{array}$ & 2013 & USA & $\begin{array}{l}\text { Integrative } \\
\text { review }\end{array}$ \\
\hline
\end{tabular}

Chart 2 - Nursing interventions used to prevent falls

\begin{tabular}{|l|l|}
\hline Title & \multicolumn{1}{c|}{ Results } \\
\hline & $\begin{array}{l}\text { - Most used fall prevention nursing } \\
\text { interventions were: inform whether the } \\
\text { child can walk or not (97.5\%), educate } \\
\text { the child/caregiver about the risk of } \\
\text { falling (92.5\%), assess the risk of falls at } \\
\text { the moment after admission (92.5\%), } \\
\text { arrange for transportation on a stretcher } \\
\text { Or wheelchair (95\%), keep one of the crates } \\
\text { the Nurse in the } \\
\begin{array}{l}\text { Prevention of Falls } \\
\text { in Children in the } \\
\text { Light of the Galway }\end{array}\end{array}$ \\
$\begin{array}{l}\text { lifted from the cradle during the child's } \\
\text { clothes/diaper change (92.5\%). } \\
\text { - Less used fall prevention nursing } \\
\text { interventions were: checking the } \\
\text { prescription of medication that alters } \\
\text { mobility and balance (72.5\%), registering } \\
\text { the child's risk of falling in the computer } \\
\text { process as well as the interventions carried } \\
\text { out in its prevention (72.5\%), report the fall } \\
\text { incidents (72.5\%). }\end{array}$ \\
\hline
\end{tabular}

Chart 1 (concluded)

\begin{tabular}{|c|c|}
\hline Title & Results \\
\hline $\begin{array}{l}\text { Development of } \\
\text { a Paediatric Fall Risk } \\
\text { And Injury Reduction } \\
\text { Program }(2016)^{(20)}\end{array}$ & $\begin{array}{l}\text { - Use an instrument to assess the risk of falls in } \\
\text { paediatrics. } \\
\text { - Guide all health professionals towards the } \\
\text { implementation of preventive measures. }\end{array}$ \\
\hline $\begin{array}{l}\text { Impatient Falls } \\
\text { in Freestanding } \\
\text { Children's Hospitals } \\
(2014)^{(21)}\end{array}$ & $\begin{array}{l}\text { - Presence of the caregiver as a strategy: } 77 \% \\
\text { of the children had an adult present at the time } \\
\text { of the fall, of which } 90 \% \text { actually witnessed } \\
\text { the fall. } \\
\text { - Strategies for reducing the risk of falls: } \\
\text { signalling children ( } 87 \%) \text { at risk of falling; } \\
\text { existence of risk communication ( } 66 \%) \text {, } \\
\text { risk registration in the care plan ( } 49 \%) \text {, risk } \\
\text { signalling in the child's identification ( } 21 \%) \text { and } \\
\text { the use of another identification method (14\%). }\end{array}$ \\
\hline $\begin{array}{l}\text { Paediatric Falls: } \\
\text { Effect of prevention } \\
\text { measures and } \\
\text { characteristics of } \\
\text { paediatric wards } \\
(2013)^{(23)}\end{array}$ & $\begin{array}{l}\text { - The fall rate was lower in units that } \\
\text { implemented the following measures: } \\
\text { "sharing information with the high-risk } \\
\text { patient", "removing obstacles in the passage } \\
\text { circuits", "using an information leaflet to } \\
\text { educate children/caregivers about the proper } \\
\text { use of crib/bed rails/protections", "use of a fall } \\
\text { risk assessment tool","select the type of bed } \\
\text { according to the child's characteristics","help } \\
\text { in walking the child with a high risk of falling", } \\
\text { "keep the unit organized", "educate the child/ } \\
\text { caregiver more than once". } \\
\text { - The fall rate was significantly higher in the } \\
\text { units that implemented the measure "educate, } \\
\text { only in verbal form, about the correct use } \\
\text { of bed rails" in relation to those that did not } \\
\text { implement it. }\end{array}$ \\
\hline $\begin{array}{l}\text { An interdisciplinary } \\
\text { momentary confluence } \\
\text { of events model to } \\
\text { explain, minimize, and } \\
\text { prevent paediatric } \\
\text { patient falls and fall- } \\
\text { related injuries (2013) }\end{array}$ & $\begin{array}{l}\text { - Start with the risk assessment of falls based } \\
\text { on scores of risk assessment tools for falls. } \\
\text { - Important to notify the cases of fall. }\end{array}$ \\
\hline
\end{tabular}

Chart 3 - Fall risk assessment instruments

\begin{tabular}{|c|c|}
\hline Title & Results \\
\hline $\begin{array}{l}\text { An Integrative } \\
\text { Review } \\
\text { of Paediatric Fall Risk } \\
\text { Assessment Tools } \\
(2017)^{(22)}\end{array}$ & $\begin{array}{l}\text { - Humpty Dumpty Falls Scale, created by Hill } \\
\text { Rodrigues (2009) (seven items evaluated: } \\
\text { age, sex, diagnosis, cognitive impairment, } \\
\text { environmental factors, response to surgery or } \\
\text { sedation/anaesthesia, use of medications). } \\
\text { - GRAF PIF, created by Graf, (2011). Five items: } \\
\text { length of stay, IV/free heparin block, physical/ } \\
\text { occupational activity, medication, orthopaedic } \\
\text { diagnosis. 75\% sensitivity and 78\% specificity. } \\
\text { - CUMMINGS has six items: history of falling, } \\
\text { physical function, cognitive/psychological } \\
\text { impairment, need for equipment and } \\
\text { medication. Three levels of risk (no risk, low } \\
\text { risk, high risk); there is no data on sensitivity or } \\
\text { specificity. } \\
\text { - I'M SAFE, created by Neiman et al. (2011) } \\
\text { assesses six items, similar to the HFDS scale, and } \\
\text { the score would be three levels (low, moderate } \\
\text { and high risk), with no risk considered. } \\
\text { - CHAMPS, created by Ramus et al. } \\
\text { (2006) assesses six items: altered state of } \\
\text { consciousness, history of previous fall, age } \\
\text { less than } 3 \text { years, mobility problems, parental } \\
\text { involvement and safety measures in place. } 75 \% \\
\text { sensitivity and } 79 \% \text { specificity. } \\
\text { - The instruments should be used in the initial } \\
\text { assessment, but they cannot be out of step with } \\
\text { the child's specificity. }\end{array}$ \\
\hline
\end{tabular}

To be continued 
Chart 3 (concluded)

\begin{tabular}{|c|c|}
\hline Title & Results \\
\hline $\begin{array}{l}\text { Development of } \\
\text { a Paediatric Fall Risk } \\
\text { And Injury } \\
\text { Reduction Program } \\
(2016)^{(20)}\end{array}$ & $\begin{array}{l}\text { The fall risk assessment scale was the Humpty } \\
\text { Dumpty Falls Scale, which includes the risk } \\
\text { factors for falls in paediatrics. }\end{array}$ \\
\hline $\begin{array}{l}\text { Impatient Falls } \\
\text { in Freestanding } \\
\text { Children's Hospitals } \\
(2014)^{(21)}\end{array}$ & $\begin{array}{l}\text { Risk assessment instruments used and their } \\
\text { sensitivity: } \\
\text { GRAF-PIF, 37\%; Humpty Dumpty Falls Scale, } \\
\text { 52\%; CHAMPS, 66\%. }\end{array}$ \\
\hline $\begin{array}{l}\text { Paediatric Falls: } \\
\text { Effect of prevention } \\
\text { measures and } \\
\text { characteristics of } \\
\text { paediatric wards } \\
(2013)^{(23)}\end{array}$ & $\begin{array}{l}\text { - Humpty Dumpty Falls Scale assesses six risk } \\
\text { factors. } 84 \% \text { sensitivity and } 24 \% \text { specificity. } \\
\text { - GRAF PIF: assesses five risk factors (previously } \\
\text { mentioned). } 75 \% \text { sensitivity and } 78 \% \text { specificity. }\end{array}$ \\
\hline $\begin{array}{l}\text { A case-control study } \\
\text { of paediatric falls } \\
\text { using electronic } \\
\text { medical records } \\
(2013)^{(24)}\end{array}$ & $\begin{array}{l}\text { - CHAMPS evaluates six items (previously } \\
\text { mentioned) } \\
\text { - GRAF PIF evaluates five items (previously } \\
\text { mentioned) } \\
\text { - Humpty Dumpty Falls Scale evaluates six items. } \\
57 \% \text { sensitivity and } 39 \% \text { specificity. }\end{array}$ \\
\hline
\end{tabular}

\section{DISCUSSION}

With the results presented and making an analysis of nursing interventions effective in preventing falls in hospitals reported by the literature and those that nurses in practice apply, it is possible to affirm that the identification of children at risk is one of the measures to be taken into account ${ }^{(21)}$, however, it is one of the least performed interventions by nurses ${ }^{(26)}$, or this identification happens in the wrong way ${ }^{(25)}$.

In order for risk identification to take place, the application of appropriate risk assessment instruments is unanimous ${ }^{(21,23)}$. Regardless of the risk assessment instrument to be used, the characteristics of each child (age, diagnosis, development) should not be forgotten ${ }^{(22)}$. All the studies carried out emphasize the importance of assessing the risk of falls as one of the first interventions to be adapted to prevent falls during children's hospitalization ${ }^{(27-28)}$. In the study on the opinion of nurses, they still reinforce that this identification of the risk must happen at the time of the child's admission ${ }^{(26)}$.

Child/family education is another of the interventions highlighted by the literature $(21,23,26-28)$. The child/family must be informed of the risk of falling and educated, at various times during hospitalization, with a view to adopting preventive measures, and for that, an information leaflet and various methodologies for transmitting information should be used and not only the verbal(23).

The selection of the type of bed according to the characteristics of the children, the organization of the care unit and the removal of obstacles in the passage circuits are major factors to avoid falling. The authors also reinforce the close monitoring of children at high risk of falling, as well as the need for their transportation to be carried out on a stretcher or wheelchair ${ }^{(23,26)}$. All the interventions presented corroborate previous studies on the topic ${ }^{(27)}$.

The registration in the risk care plan and the interventions performed are activities less used by the studies analyzed and less reported by nurses ${ }^{(23,26)}$.

There are measures that, when implemented, do not produce a decrease in the fall rate, namely: placing the child at high risk of falling close to the nursing unit, education on cleaning the bed and using slip-resistant shoes ${ }^{(23)}$.

The influence of an adult's presence on the fall rate was also reported: most children had an adult present at the time of the fall. This is due to the fact that parents feel that the hospital is a safe environment, not being aware of the risks to which their children are exposed ${ }^{(21)}$. The presence of parents has been the subject of research since the first studies on falls in children, and the results show that they are present at the time of the fall(27-28).

Regarding the notification of the fall incident, the authors refer that it is one of the least used interventions by the nursing team, and the nurses themselves assume that ${ }^{(25-26)}$.

As for the fall prevention program, as already mentioned, one should start with the assessment of the risk of falls using instruments validated based on the score they present ${ }^{(25-26)}$.

The Humpty Dumpty Falls Scale (HDFS) is the most analyzed scale ${ }^{(20-24)}$, has a sensitivity of $57 \%$ and a specificity of $39 \%$, being also the most complete scale in relation to the evaluated items $s^{(21-24)}$.

It was created by Hill Rodrigues et al. in 2009 and resulted from data analysis (nursing records) of a study carried out by Miami Children's Hospital, with 153 children who suffered a fall during 2005-2006. It was found that the majority occurred in children under the age of 3 and over 13 years old, hospitalized with neurological disease (seizures), respiratory diseases (asthma) and gastrointestinal diseases (dehydration or vomiting).

This instrument assesses seven items: age; sex; diagnosis; cognitive disabilities; environmental factors; reaction to surgery/ sedation/anaesthesia; and drug consumption. The evaluation results in a minimum of 7 and a maximum of 23 points, with a low risk of 7-11; and high risk, score 1223 . After defining the risk pattern, the corresponding protocol is applied, in order to guide the intervention of the nursing team in a more structured way ${ }^{(20-24)}$.

Studies also suggest other risk assessment tools:

- Graf-PIF - created by Graf in 2011 and evaluates five items: length of stay, IV block/free heparin, physical/occupational activity, medication, orthopaedic diagnosis. It obtained a sensitivity of $75 \%$ and a specificity of $76 \%$. The factors associated with falls in paediatrics were physiological (61\%), mainly associated with neurological changes, accidental factors (33\%), especially in children over 10 years and adolescents, and unforeseen physiological falls (6\%); no additional tests were found for this instrument ${ }^{(21-24)}$.

- CHAMPS - created by Razmus et al. in 2006, it was developed based on a study of evaluation of falls in adults (Morse and Hendrich scale). CHAMPS is the acronym for the six items to be evaluated: change in mental status, age less than 3 years, history of previous fall, reduced mobility, caregiver involvement, safety actions. There are studies underway to validate the use of this scale in paediatrics ${ }^{(21-22,24)}$.

- Cummings Pediatric Fall Assessment Scale - Developed in 2006, it evaluates six items: history of fall, physical function, cognitive/psychological impairment, need for equipment and medication. In this assessment, three levels of risk are considered (no risk, low risk, high risk) ${ }^{(22)}$.

- I'M SAFE - Published in 2011, evaluates six items. Similar to the HDFS scale, the score would be three levels (low, moderate and high risk), with no risk being considered with the use of this scale(22). 
In a comparison between the items evaluated by the different instruments, the Cummings and Graf-PIF scale included only the falls resulting from intrinsic factors. The Humpty Dumpty Falls Scale excluded environmental and organizational factors ${ }^{(22)}$.

\section{Study limitations}

The time limitation to produce this article was one of the difficulties felt as well as the lack of scientific studies in Portugal on the subject under study.

\section{Contributions to the Area}

The accomplishment of this article allowed the awareness of the reality of falls in children, in a hospital context, with a strong contribution to the work context through the creation of an intervention program for the prevention of falls in children, using the most effective interventions. and a risk assessment instrument more appropriate to paediatric age, in this case the Humpty Dumpty Falls Scale. All the work developed allowed the creation and implementation of a fall prevention program in a hospital, in a hospital in Portugal, based on evidence-based practice.

\section{CONCLUSIONS}

The promotion of a safe environment in health units is a concern for nurses. Fall prevention will therefore be an important aspect of promoting child and youth safety.

The present scoping review has become important to raise awareness of the problem and to systematize the nursing interventions that best prevent children from falling into the hospital.

Of the reported nursing interventions, the importance of educating children and family about the risk of falling is highlighted, as reported in previous studies. However, it is emphasized that, for this, we must use different methodologies than just the verbal. This same education must be reinforced throughout the hospitalization and not only provided at the time of admission. Thus, empowerment is promoted and the child/family junction becomes active and involved in the health and safety promotion process.
As was already reported in the first studies in this area, the presence of parents still does not offer additional protection against the occurrence of falls but may create a false sense of protection. Therefore, they must also be included in educational actions.

For a correct intervention, it is necessary and useful to use systematic and objective instruments for risk assessment, and this assessment should be part of the individual care plan. Next, risk assessment is itself a nursing intervention.

Of the scales referred to by the studies, the Humpty Dumpty Falls Scale was the most analyzed and studied, however it presented errors in the classification of children at high risk, reinforcing the need for a correct assessment of each of its items.

Also noteworthy is the low rate of notification of the occurrence of falls, which is so important for the correct retrospective characterization of the incident, so that there is continuous restructuring of prevention measures and improvement of safety conditions. Furthermore, it should be noted that the nurses themselves assume that this same notification intervention is often not performed.

Most falls can be prevented, and such prevention is a sensitive focus on nursing care. For an adequate intervention, it is necessary to use systematized instruments and objectives of risk assessment of the patient. So, regardless of the instrument selected, it is important that it is specific and sensitive to the population concerned and that it is part of the nurse's practice.

Nurses must remain vigilant, monitor children frequently, introduce the score of the instruments in the processes (written/computerized), implement preventive measures for falls and document their effectiveness, then creating fall prevention programs. It is equally essential to include children and caregivers in the whole process.

Thus, the nurse, especially the specialist in child and pediatric health, carries out their activity taking into account the skills acquired with regard to the prevention of risk situations and health-promoting interventions.

A fall prevention policy and an appropriate program for the unit can increase the awareness of the multidisciplinary team and the family, as well as decrease fall rates in the pediatric population, improving safety and quality of care provided.

\section{REFERENCES}

1. Joint Commission Internacional; Joint Commission on Accreditation of Hearthcare Organizations. Padrões de acreditação Joint Commission Internacional para hospitais. Normas Internacionais de Segurança do Paciente - IPSG. 2015. 29-30p

2. Ordem dos Enfermeiros (PT). Regulamento de competências comuns do Enfermeiro Especialista. Lisboa; 2010

3. World Health Organization (WHO). Relatório Mundial sobre Prevenção de Acidentes nas crianças. [Internet] 2004 [cited 2018 Apr 04 ] Available from: http://www.who.int/violence_injury_prevention/child/injury/world_report/Falls_portuguese.pdf

4. Ministério da Saúde (PT). Direção Geral de Saúde. Programa Nacional de Saúde Infantil e Juvenil. Lisboa; 2013

5. Ordem dos Enfermeiros (PT). Regulamento n 222/2018: Regulamento de Competências Específicas do Enfermeiro Especialista em Enfermagem de Saúde Infantil e Pediátrica. Diário da República. 2a Serie - nº 422/2018. 12 de julho de 201819192 - 19194p.

6. Pender N, Murdaugh C, Parsons M. Health Promotion in Nursing Practice. 6ed. Ed. Boston: Pearson Education; 2011

7. Associação para a Promoção da Segurança Infantil (APSI). Resumo do relatório: quedas em Crianças e Jovens. [Internet] 2014 [cited 2018 Apr 04] Available from: http://apsi.org.pt/images/Documentos/EstudodasQuedas20002013_Resumo.pdf

8. Associação para a Promoção da Segurança Infantil (APSI); Plano de Ação para a Segurança Infantil. [Internet] 2011 [cited 2018 Apr 04 ] Available from: http://apsi.org.pt/images/Documentos/PASI_2011.pdf 
9. Associação para a Promoção da Segurança Infantil (APSI); Relatório de Avaliação de Segurança Infantil em Portugal. [Internet] 2017 [cited 2018 Apr 04] Available from: http://www.apsi.org.pt/images/25anos/PDF/APSI_RELATORIO_SEGURANCA_INFANTIL_2017.pdf

10. World Health Organization (WHO). Word Report on Child Injury Prevention. [Internet] 2008 [cited 2018 Apr 04]:101-15 Available from: http://apps. who.int/iris/bitstream/handle/10665/43851/9789241563574_eng.pdf;jsessionid=CC48F22D29CD9FA0A007F7D6CA5EDDDD?sequence

11. Conselho Internacional de Enfermagem. Classificação Internacional para Prática de Enfermagem (CIPE) - 2017: Lisboa: Lusodidata, Ida;2017

12. Yuan-Yuan G, Koen B, Yicheng N, Jan A, Jan G. Review on prevention of falls in hospital settings. Chinese Nurs Res. 2016;3:7-10. doi:10.1016/j. cnre.2015.11.002

13. Almis H, Bucak IH, Konca C, Turgut M. Risk factors related to caregivers in hospitalized children's falls. J Pediatr Nurs. 2016;32:3-7 doi: 10.1016/j.pedn.2016.10.006

14. Ministério da Saúde (PT). Decreto-Lei n²8/2015. Diário da República. 2a série - n¹400-A /2015 - 10 de fevereiro de 2015; p. 3882-(2) $-3882-(10)$

15. NANDA Internacional. Diagnósticos de Enfermagem da NANDA International: Definições e classificações 2015-2017. Artmed. Porto Alegre: 2015

16. Direção Geral de Saúde (PT). Estrutura Concetual da Classificação Internacional sobre Segurança do Doente. Lisboa: 2010

17. Ordem dos Enfermeiros (PT). Tomada de posição sobre a segurança do cliente. Lisboa: 2006

18. Almeida R, Abreu C, Mendes A. Quedas em doentes hospitalizados: contributos para uma prática baseada na prevenção. Rev Enferm Ref[Internet] 2010 [cited 2018 Apr 24];2:163-72. Available from: http://www.scielo.mec.pt/pdf/ref/vserllIn2/serllln2a17.pdf

19. Briggs J. The Joanna Briggs Institute Reviewers Manual. Austrália: Supplement: 2015

20. Kramlich DL, Dende D. Development of a pediatric fall risk and injury reduction program. J Pediatr Nurs. 2016;42(2):77-82 doi: 10.1016/j. pedn.2018.02.010

21. Jamerson P, Graf E, Messmer P, Fields H, Barton S, Berger A, et al. Inpatient Falls in Freestanding Children's Hospitals. J Pediatr Nurs[Internet]. 2014 [cited 2018 Apr 24];40(3):127-35 Available from: https://pubmed.ncbi.nlm.nih.gov/25134226/

22. DiGerolamo K, Davis KF. An integrative review of pediatric fall risk assessment tools. J Pediatr Nurs. 2017;34:23-28 doi: 10.1016/j. pedn.2017.02.036

23. Fujita Y, Fujita M, Fujiwara C. Pediatric Falls: effect of prevention measures and characteristics of pediatric wards. Japan J Nurs Sci. 2013;10:223-231 doi:10.1111/jjns.12004

24. Messmer PR,Williams PD, Williams AR. A case-control study of pediatric falls using electronic medical records. Rehabil Nurs. 2013;38(2): 7379 doi: $10.1002 / \mathrm{rnj} .73$

25. Ryan-Wenger NA, Dufek JS. An interdisciplinary momentary confluence of events model to explain, minimize, and prevent pediatric patient falls and fall-related injuries. J Spec Pediatr Nurs. 2013;18(1):4-12 doi:10.1111/jspn.12009

26. Gurgel S, Ferreira A, Sandoval L, Araújo P, Galvão M, Lima F. Competências do enfermeiro na prevenção de quedas em crianças á luz do Consenso de Galway. Texto Contexto Enferm. 2017;26(4). doi: 10.1590/0104-070720170003140016

27. Child Health Corporation of America Nursing Falls Study Task Force. Pediatric falls: state of the science. J Pediatr Nurs[Internet]. 2009 [cited 2018 Apr 24];35(4):227-31 Available from: http://www.pediatricnursing.net/ce/2011/article35227231.pdf

28. Graf E. Magnet children's hospitals: leading knowledge development and quality standards for inpatient pediatric fall prevention programs. J Pediatr Nurs. 2011;26(2):122-7. doi: 10.1016/j.pedn.2010.12.007 